\title{
Optimization of Metal Recovery from MSWI Fly Ash by Acid Leaching: Findings from Laboratory- and Industrial-Scale Experiments
}

\author{
Gisela Weibel $^{1, *(\mathbb{D})}$, Anna Zappatini ${ }^{1}{ }^{(\mathbb{D}}$, Mirjam Wolffers ${ }^{1}(\mathbb{D})$ and Stefan Ringmann ${ }^{2}$ \\ 1 Institute of Geological Sciences, University of Bern, Baltzerstrasse 1+3, 3012 Bern, Switzerland; \\ anna.zappatini@geo.unibe.ch (A.Z.); mirjam.wolffers@geo.unibe.ch (M.W.) \\ 2 KVA Linth, Im Fennen 1A, 8867 Niederurnen, Switzerland; s.ringmann@kva-linth.ch \\ * Correspondence: gisela.weibel@geo.unibe.ch
}

Citation: Weibel, G.; Zappatini, A.; Wolffers, M.; Ringmann, S.

Optimization of Metal Recovery from MSWI Fly Ash by Acid Leaching: Findings from Laboratory- and Industrial-Scale Experiments. Processes 2021, 9, 352. https:// doi.org/10.3390/pr9020352

Academic Editors: Daniel Vollprecht and Renato Sarc

Received: 30 November 2020

Accepted: 10 February 2021

Published: 14 February 2021

Publisher's Note: MDPI stays neutral with regard to jurisdictional claims in published maps and institutional affiliations.

Copyright: () 2021 by the authors. Licensee MDPI, Basel, Switzerland. This article is an open access article distributed under the terms and conditions of the Creative Commons Attribution (CC BY) license (https:// creativecommons.org/licenses/by/ $4.0 /)$.

\begin{abstract}
A major part of Swiss fly ashes (FA) from municipal solid waste incineration (MSWI) are treated with the acid fly ash leaching process (FLUWA) in order to recover heavy metals prior to deposition. The FLUWA process uses scrub water from wet flue gas cleaning to leach heavy metals from FA. The leaching efficiency is strongly dependent on the leaching conditions (e.g., $\mathrm{pH}$, Eh, L/S-ratio). This case study presents the optimization of the FLUWA process at the MSWI plant Linth, Switzerland, through determination of ideal process parameters for optimal metal recovery. By means of laboratory- and industrial-scale experiments, the process was adjusted towards a more efficient leaching of $\mathrm{Zn}, \mathrm{Pb}, \mathrm{Cu}$, and $\mathrm{Cd}$. This included the use of an oxidizing agent (hydrogen peroxide). Laboratory experiments proved to be a powerful tool for simulating process optimizations at industrial scale. An ideal leaching $\mathrm{pH}$ of 3.8 was determined and it was observed that the process stability is significantly influenced by the L/S-ratio applied to the leaching process. In the course of the study, the recovery could be improved to $67 \% \mathrm{Zn}, 66 \% \mathrm{~Pb}, 30 \% \mathrm{Cu}$, and $91 \% \mathrm{Cd}$. It can be concluded that for optimal metal recovery the process has to be individually adjusted to the composition of the processed FA and scrub water of each specific FLUWA process.
\end{abstract}

Keywords: MSWI fly ash; acid leaching; heavy metal recovery; process optimization

\section{Introduction}

In Switzerland, approximately 80,000 tons of fly ash (FA) from municipal solid waste incineration (MSWI) arise annually [1]. Due to the incineration of heavy metal bearing objects (e.g., electronics or batteries) contained in the waste, the FA is highly enriched in heavy metals. Swiss FA contain up to $6.6 \mathrm{wt} . \% \mathrm{Zn}, 1.9 \mathrm{wt} . \% \mathrm{~Pb}, 0.6 \mathrm{wt} . \% \mathrm{Cu}$, and $0.05 \mathrm{wt} . \%$ $\mathrm{Cd}$ [2], and such elevated heavy metal concentrations have been observed in ashes from other countries [3]. Thus, FA comprises a large potential for recyclable metals where mainly the elements $\mathrm{Zn}, \mathrm{Pb}, \mathrm{Cu}$, and $\mathrm{Cd}$ are of interest. In recent years, a research focus was put on the optimization of the heavy metal separation and recovery from FA. Acid leaching was shown to be the most effective method to mobilize heavy metals from FA [4-11].

Since 1995, the acid fly ash leaching process (FLUWA process) has been established in Switzerland. Therein, heavy metals are extracted from FA using scrub water [12-14], a liquid residue from wet flue gas cleaning. The heavy metals are accumulated in the leachate which can later be used for heavy metal recovery. The aim of the FLUWA process is to produce a leachate that contains high concentrations of the metals to be recovered. The metal recoveries achieved in the FLUWA process depend on the properties of the FA as well as on the leaching conditions. The main process parameters that influence metal mobilization are $\mathrm{pH}$ value and the oxidation-reduction potential [15]. The leaching $\mathrm{pH}$ is defined by the alkalinity of the FA and the amount of acid accumulated from the scrub water. In order to reach sufficient acidic process conditions for mobilizing the heavy 
metals, the addition of additional acid is often necessary. The $\mathrm{pH}$ value defines whether the mobilized metals reprecipitate during extraction, making them unavailable for recovery. In order to create ideal conditions for the extraction of redox-sensitive metals, an oxidant (e.g., hydrogen peroxide) is necessary during the FLUWA process. Oxidizing conditions during metal extraction are a prerequisite to suppress the reductive precipitation of elements such as $\mathrm{Cu}, \mathrm{Pb}$, and to a minor extent, $\mathrm{Cd}$ [16-18]. Other factors influencing FA leaching are temperature and reaction time. A temperature of ca. $60^{\circ} \mathrm{C}$ arises from the mixing of FA and scrub water during the FLUWA process. The reaction time is dependent on the number of extraction reactors used. Three reactors connected in series are prevalent in Switzerland. An extraction time of one hour, cumulated from 20 min per reactor, has commonly been established. Filtration of the ash slurry by vacuum-belt filtration yields a metal-depleted filter cake and a metal-enriched leachate. The filter cake has less impact on the environment and can be deposited together with bottom ash on a landfill type D according to the Swiss Waste Ordinance [19]. The metalliferous leachate is precipitated to a hydroxide sludge. The hydroxide sludge can so far only be processed abroad as hazardous waste. With the foundation of SwissZinc AG, a central treatment facility for hydroxide sludge is pursued. Implementation is expected by the end of 2023 [20]. This plant will apply a system based on the FLUREC process to produce high-purity zinc and as byproducts $\mathrm{Pb}, \mathrm{Cu}$ and $\mathrm{Cd}$ in a recoverable form [12]. The prescription of recovering heavy metals from FA and recovery of metals is prescribed from 2026 onwards in Switzerland [19]. Therefore, the investigation of the FLUWA process is of increasing interest to improve heavy metal separation and to estimate the limiting factors of metal depletion.

With this study, the optimization of the FLUWA process at the Swiss MSWI plant Linth is shown. The goal of the study was to determine the process parameters for an optimal recovery for $\mathrm{Zn}, \mathrm{Pb}, \mathrm{Cu}$ and $\mathrm{Cd}$. This was achieved by performing experiments both on laboratory and industrial scale. The laboratory-scale experiments allow the preliminary examination of the influence of different parameters on the FA leaching process. As the operation on the industrial process relies on many more variables which cannot all be varied or excluded, the laboratory-scale experiments render it possible to better isolate and examine the influence of selected parameters. These initial experiments also deliver an idea of metal recoveries attainable for the specific FLUWA process. In the course of the study, three industrial-scale experiments were carried out. Such experiments represent the reality of a large-scale operation which runs continuously over hours and days where the input materials may also vary over time. Parallel to each industrial-scale experiment, laboratory-scale experiments were carried out with the same process parameters. This indicates to what extent laboratory-scale experiments can model the industrial FLUWA process. In a first experiment, the "current state" of the FLUWA process was sampled in order to make statements about the operational state and the efficiency of the metal recovery. The successive two industrial-scale experiments were performed to implement and verify the optimized operating parameters determined in the laboratory.

\section{Materials and Methods}

\subsection{FLUWA Process at MSWI Plant Linth: Process Conditions and Composition of FA}

A total of $6500 \mathrm{t} / \mathrm{y}$ of FA are acid leached in the FLUWA process at MSWI plant Linth. In addition to FA from the plant's own waste incineration, external FA from three other Swiss MSWI plants are treated with the FLUWA process. The FLUWA of the MSWI plant Linth has three reactors operating in series, each with a volume of about $3 \mathrm{~m}^{3}$ with an average residence time of about 45 min (Figure 1).

Approximately $9000 \mathrm{~m}^{3}$ of acid scrub water with a hydrochloric acid load of $1600 \mathrm{t}$ $\mathrm{HCl}(32 \%)$ and $5500 \mathrm{~m}^{3}$ of alkaline scrub water with a sulfur load of $275 \mathrm{t}$ from the wet flue gas cleaning process are available annually for the extraction of the FA. Depending on the experiment, an amount of ca. 2-3 t of FA was leached with $6 \mathrm{~m}^{3}$ of acid and $3 \mathrm{~m}^{3}$ of alkaline scrub water per hour of FLUWA operation. When necessary, $\mathrm{HCl} 32 \%$ was added 
for $\mathrm{pH}$ control. For the optimization tests, a temporary hydrogen peroxide $\left(\mathrm{H}_{2} \mathrm{O}_{2}, 30 \%\right)$ feed line was built into reactor 1 .

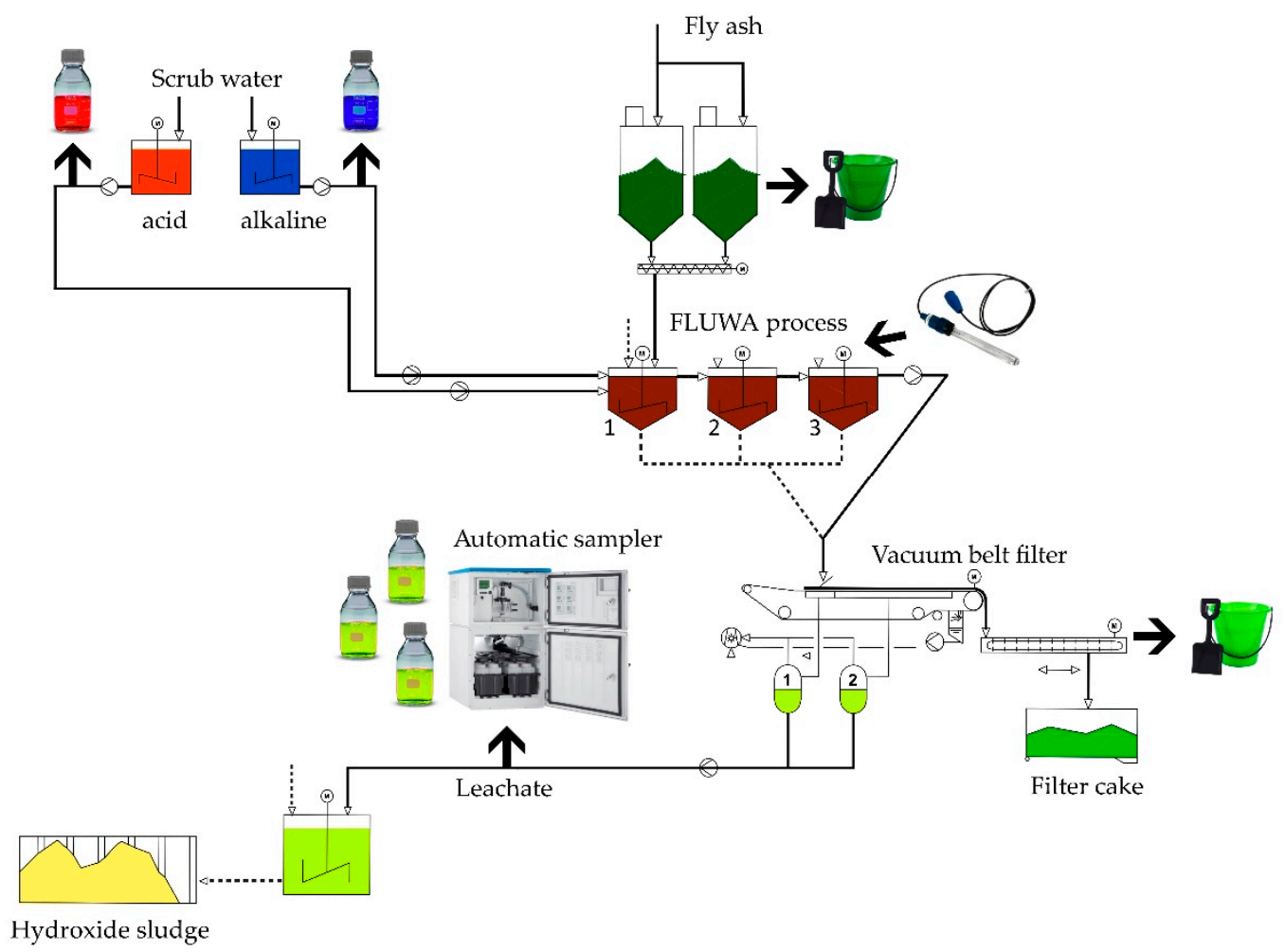

Figure 1. Scheme of the acid fly ash leaching (FLUWA) process and sampling locations during the industrial-scale experiments.

Table 1 summarizes the mean value of the FA composition over the entire project duration and indicates the standard deviation for each element concentration. Compared to the average heavy metal concentrations of Swiss fly ash [2], the FA treated at MSWI plant Linth shows elevated $\mathrm{Zn}(52,593 \mathrm{mg} / \mathrm{kg}), \mathrm{Pb}(9378 \mathrm{mg} / \mathrm{kg}), \mathrm{Cu}(2671 \mathrm{mg} / \mathrm{kg})$ and Cd $(332 \mathrm{mg} / \mathrm{kg})$ concentrations.

Table 1. Mean elemental composition in $\mathrm{mg} / \mathrm{kg}$ and standard deviation of the fly ash (FA) treated at municipal solid waste incineration (MSWI) plant Linth.

\begin{tabular}{cccc}
\hline & Mean Concentration of FA Treated at MSWI Plant Linth \\
\hline $\mathrm{Al}$ & 30,278 & \pm & 2268 \\
$\mathrm{Ba}$ & 2152 & \pm & 208 \\
$\mathrm{Br}$ & 3255 & \pm & 174 \\
$\mathrm{Ca}$ & 144,928 & \pm & 8696 \\
$\mathrm{Cd}$ & 332 & \pm & 34 \\
$\mathrm{Cl}$ & 97,707 & \pm & 2892 \\
$\mathrm{Cr}$ & 684 & \pm & 291 \\
$\mathrm{Cu}$ & 2671 & \pm & 1271 \\
$\mathrm{Fe}$ & 19,274 & \pm & 3590 \\
$\mathrm{~K}$ & 52,755 & \pm & 67 \\
$\mathrm{Mn}$ & 881 & \pm & 16 \\
$\mathrm{Ni}$ & 132 & \pm & 117 \\
$\mathrm{P}$ & 3851 & \pm & 973 \\
$\mathrm{~Pb}$ & 9378 & \pm & 9450 \\
$\mathrm{~S}$ & 61,619 & \pm & 273 \\
$\mathrm{Sb}$ & 2621 & \pm 1562 \\
$\mathrm{Si}$ & 77,689 & \pm & 139 \\
$\mathrm{Sn}$ & 1447 & \pm & 7371 \\
$\mathrm{Ti}$ & 9783 & \pm & \\
$\mathrm{Zn}$ & 52,593 & & \pm
\end{tabular}




\subsection{Chemical Analysis}

All solids were dried at $105^{\circ} \mathrm{C}$ until constant weight and then ground with a ball mill. Then, $4.0 \mathrm{~g}$ of the ground sample was mixed with $0.9 \mathrm{~g}$ binder (Fluxana Cereox ${ }^{\circledR}$ ) and pressed into a powder pill. The analysis of solids was carried out using X-ray fluorescence analysis on a Spectro Xepos ED-XRF. The elements $\mathrm{Al}, \mathrm{Ca}, \mathrm{Cd}, \mathrm{Cu}, \mathrm{Fe}, \mathrm{K}, \mathrm{Mn}, \mathrm{Pb}, \mathrm{S}, \mathrm{Sb}$, $\mathrm{Si}$, Ti and $\mathrm{Zn}$ were determined with matrix-adapted calibration for FA or filter cake. The elements $\mathrm{Ba}, \mathrm{Br}, \mathrm{Cl}, \mathrm{Cr}, \mathrm{Ni}, \mathrm{Pb}$ and $\mathrm{Sn}$ were determined with the Turboquant method.

The liquid samples (leachates) were diluted with $1 \% \mathrm{HNO}_{3}\left(\mathrm{HNO}_{3}, 1 \%\right.$, VWR Chemicals, AnalaR Normapur) and analyzed with a Spectroblue SOP ICP-OES. The calibration was performed using Merck Multielement Standard IV and the analyses were checked with a check standard (Merck VIII Multielement Standard). The analytical error amounts to $\pm 5 \%$ for all elements except $\mathrm{Na}, \mathrm{K}, \mathrm{Ca}, \mathrm{Sb}$ and $\mathrm{S}$ that showed $\pm 10 \%$ error based on multiple measurements of certified standard solutions.

\subsection{Laboratory-Scale Experiments}

The preliminary laboratory-scale experiments were carried out in order to determine the influence of different conditions and parameters on the heavy metal recovery. It is already known from preliminary studies that mainly $\mathrm{pH}$ value, $\mathrm{H}_{2} \mathrm{O}_{2}$ dosage and L/S-ratio need to be investigated to optimize a specific FLUWA process [15]. Therefore, six different experiments were performed at laboratory scale (Table 2): at extraction $\mathrm{pH}$ of 3.8 and 4.5, with a concentration of $0,20,40$ and $60 \mathrm{~L} \mathrm{H}_{2} \mathrm{O}_{2} / \mathrm{t}$ ash and with two different $\mathrm{L} / \mathrm{S}$ ratios of 2 and 3 . The experiments were performed twice to ensure reproducibility and the mean value used as result. In addition to the three industrial-scale experiments, laboratory-scale experiments were performed under conditions simulating the specific process conditions as good as possible.

Table 2. Experimental setups for laboratory-scale experiments.

\begin{tabular}{cccc}
\hline Parameter & $\mathbf{p H}$ & Redox $\left(\mathbf{L} / \mathbf{t} \mathbf{H}_{\mathbf{2}} \mathbf{O}_{\mathbf{2}}\right)$ & $\mathbf{L} / \mathbf{S}\left(\mathbf{m}^{\mathbf{3}} / \mathbf{t}\right)$ \\
\hline Experiment 1 & 3.8 & 40 & 2 \\
Experiment 2 & 4.5 & 40 & 2 \\
Experiment 3 & 3.8 & 0 & 2 \\
Experiment 4 & 3.8 & 20 & 2 \\
Experiment 5 & 3.8 & 60 & 2 \\
Experiment 6 & 3.8 & 40 & 3 \\
\hline
\end{tabular}

For all laboratory tests, $75 \mathrm{~g}$ FA was added to the corresponding amount of acid scrub water required for the given L/S-ratio. For each experiment, $70 \%$ acid scrub water and $30 \%$ alkaline scrub water $(\mathrm{HCl}=1.26-1.42 \mathrm{~mol} / \mathrm{L})$ were used. Upon mixing the FA with scrub water, the neutralization heat almost instantly led to a rise in temperature in the reactor to approximately $60-65^{\circ} \mathrm{C}$. A heating stirrer including a thermostat was used to maintain a temperature of $60^{\circ} \mathrm{C}$ while stirring the mixture at ca. $400 \mathrm{rpm}$. The neutralization occurring upon mixing also led to a pronounced increase in $\mathrm{pH}$ value. The $\mathrm{pH}$ was corrected to the desired value ( $\mathrm{pH} 3.8$ or 4.5 ) by the dropwise addition of $\mathrm{HCl}, 32 \%$ (VWR Chemicals, AnalaR Normapur) to the mixture. The dosing of $\mathrm{H}_{2} \mathrm{O}_{2}(30 \%$, Merck, stabilized, for synthesis) was carried out in several small portions within the first $20 \mathrm{~min}$ of leaching to simulate the continuous peroxide addition to reactor 1 on the industrial scale. The total leaching time applied was $60 \mathrm{~min}$. The $\mathrm{pH}$ and temperature of the suspension were documented as well as the quantities of each reagent added. At the end of the leaching time the mixture was hot filtered. The filter cake was washed twice with deionized water (50 $\mathrm{mL}$ each, $18.2 \mathrm{M} \Omega \cdot \mathrm{cm}$ ) and the combined leachate was rapidly conserved by diluting it 1:100 (vol/vol) with nitric acid $\left(\mathrm{HNO}_{3}, 1 \%\right.$, VWR Chemicals, AnalaR Normapur). 


\subsection{Industrial-Scale Experiments}

A main goal of the industrial-scale experiments was to collect time-dependent data on the industrial operation. This in turn allowed to identify and address the problems related to the continuous large-scale industrial process. The experimental setups of the three industrial-scale experiments are shown in Table 3. All material flows were sampled at defined time intervals adapted to the operation (mostly in 30-min intervals). The sampling included FA, scrub water (separated acid and alkaline), filter cake from vacuum belt filter, and leachate (Figure 1). The leachate samples were taken at defined time intervals (sampling in $7 \mathrm{~min}$ intervals and mixed to samples of $28 \mathrm{~min}$ ) by means of an automatic sampler (CSF 48, Endress+Hauser). The sample preparation for the leachates was carried out as soon as possible on site. This includes the uptake of the mass flow (present volume of leachate per unit of time), the filtration and the subsequent stabilization of the sample with $\mathrm{HNO}_{3}(30 \%$, VWR Chemicals, AnalaR Normapur) prior to analysis. In addition, $\mathrm{pH}$ value, redox potential, and oxygen content were measured in all three reactors at defined time intervals (usually every $15 \mathrm{~min}$ ).

Table 3. Experimental setups for industrial-scale experiments.

\begin{tabular}{cccc}
\hline Parameter. & $\mathbf{p H}$ & Redox $\left(\mathrm{L} / \mathbf{t} \mathbf{H}_{\mathbf{2}} \mathbf{O}_{\mathbf{2}}\right)$ & $\mathbf{L} / \mathbf{S}\left(\mathbf{m}^{\mathbf{3}} / \mathbf{t}\right)$ \\
\hline Experiment A & 6 & 0 & 3 \\
Experiment B & 4.5 & 40 & 3 \\
Experiment C & 4 & 40 & 4 \\
\hline
\end{tabular}

\subsection{Calculation of the Leaching Recovery}

When performing laboratory-scale experiments, mass balance is easily determinable because all volumes, concentrations and weights can be determined. Therefore, the calculation of the metal recovery was performed as follows (Formulas (1) and (2)):

$$
\text { recovery }(\%)=100 \cdot\left(1-\frac{c(\text { filter cake })\left[m g \cdot k g^{-1}\right] \cdot m_{\text {filter cake }}[k g]}{c(\text { fly ash })\left[m g \cdot \mathrm{kg}^{-1}\right] \cdot m_{\text {fly ash }}[\mathrm{kg}]+c(\text { scrub water })\left[\mathrm{mg}^{-1} \mathrm{~L}^{-1}\right] \cdot V_{\text {scrub water }}[L]}\right)
$$

where $m$ is the mass of filter cake or FA. For the laboratory tests, the recovery can also be calculated via the concentration in the leachate:

$$
\text { recovery }(\%)=100 \cdot \frac{c(\text { leachate })\left[m g \cdot L^{-1}\right] \cdot V_{\text {leachate }}[L]}{c(\text { fly ash })\left[m g \cdot \mathrm{kg}^{-1}\right] \cdot m_{\text {fly ash }}[\mathrm{kmg}]+c(\text { scrub water })\left[m g \cdot \mathrm{L}^{-1}\right] \cdot V_{\text {scrub water }}[L]}
$$

where $V_{\text {leachate }}$ is the volume of the leachate at the end of the experiment. The mass balance is then calculated using Formula (3):

mass balance $(\%)=100 \cdot \frac{\left.(c \text { leachate })\left[m g \cdot L^{-1}\right] \cdot V_{\text {leachate }}[L]\right)+\left(c(\text { filter cake })\left[m g \cdot k g^{-1}\right] \cdot m_{\text {filter cake }}[k g]\right)}{c(\text { fly ash })\left[m g \cdot k g^{-1}\right] \cdot m_{\text {fly ash }}[k g]+c(\text { scrub water })\left[m g \cdot L^{-1}\right] \cdot V_{\text {scrub water }}[L]}$

As the FLUWA process at MSWI plant Linth is conducted in a continuous process, this weight difference is in most cases not known. The mobilization of the acid-soluble components of the FA (e.g., salts) leads to a reduction of mass of the filter cake. Therefore, the mass loss on the industrial scale is often calculated indirectly by measuring and balancing the "inert elements" (e.g., $\mathrm{Al}, \mathrm{Si}, \mathrm{P}, \mathrm{Ca}, \mathrm{Ti}, \mathrm{Cr}, \mathrm{Fe}, \mathrm{Ni}, \mathrm{Sb}$ and $\mathrm{Ba}$ ). These elements are hardly mobilized under the respective extraction conditions and therefore accumulate in the filter cake relative to its total mass. Assuming that the absolute amounts of these elements in FA 
and filter cake are equal and only their concentrations differ, the average enrichment factor of the inert elements can be used as a proxy for the mass loss (Formulas (4) and (5)).

$$
\text { enrichment factor }=\frac{\sum\left(\frac{c_{\text {inert }}(\text { filter cake })\left[\mathrm{mg} \cdot \mathrm{kg}^{-1}\right]}{c_{\text {inert }}(\text { fly ash })\left[\mathrm{mg} \cdot \mathrm{kg}^{-1}\right]}\right)}{\text { number of inert elements used }}
$$

where $c$ is concentration of the respective element.

$$
\text { recovery }(\%)=100 \cdot\left(1-\frac{c(\text { filter cake })\left[\mathrm{mg}^{\prime} \cdot \mathrm{kg}^{-1}\right]}{c(\text { fly ash })\left[\mathrm{mg} \cdot \mathrm{kg}^{-1}\right] \cdot \text { enrichment factor }}\right)
$$

\section{Results}

\subsection{Laboratory-Scale Experiments}

Figure 2 shows the results obtained in the laboratory-scale experiments. The results of these experiments allowed the identification of optimal parameters for the industrial-scale FLUWA operation at MSWI plant Linth.
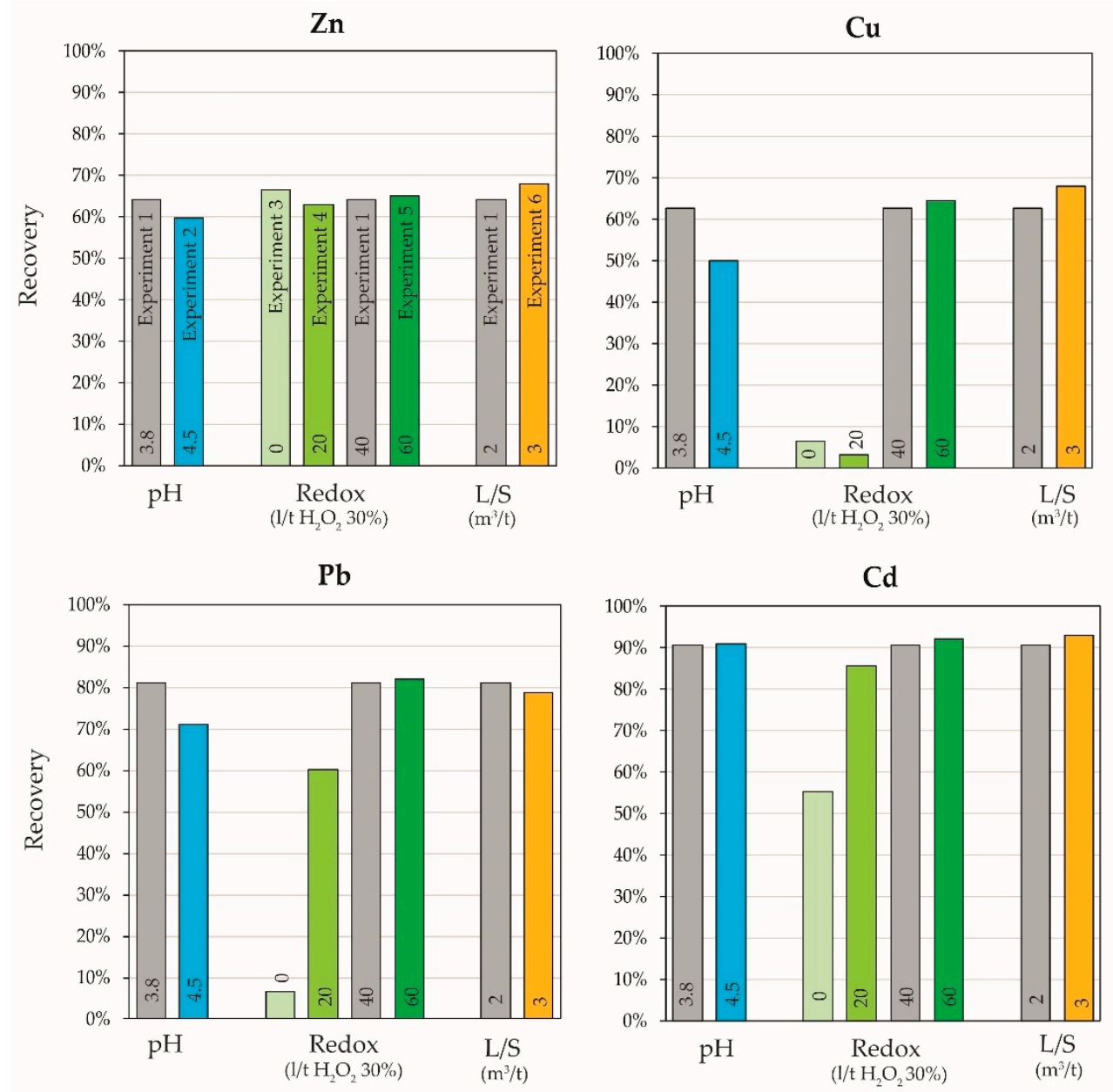

Figure 2. Recoveries of laboratory-scale experiments for $\mathrm{Zn}, \mathrm{Cu}, \mathrm{Pb}$ and $\mathrm{Cd}$ to simulate the FLUWA process under different leaching conditions.

The variation of the three parameters $\mathrm{pH}$, redox and $\mathrm{L} / \mathrm{S}$ ratio throughout the experiments affected the metal recoveries in different ways. A leachate $\mathrm{pH}$ value of 4.0 and above at the end of the experiment resulted in diminished recoveries of all four elements studied (Experiment 2). This effect was most pronounced for $\mathrm{Cu}$ and $\mathrm{Pb}$. If the $\mathrm{pH}$ is 
adjusted to a value of 3.8 at the end of the leaching process, the recoveries of $\mathrm{Cu}$ and $\mathrm{Pb}$ are $10 \%$ higher (Experiment 1 ). The oxidizing conditions when adding $\mathrm{H}_{2} \mathrm{O}_{2}$ to the ash slurry mainly affect the elements $\mathrm{Cu}$ and $\mathrm{Pb}$ and to a minor extent $\mathrm{Cd}$. Without the addition of an oxidizing agent, $67 \% \mathrm{Zn}$ and $55 \% \mathrm{Cd}$ are recovered from FA whereas the recoveries of $\mathrm{Pb}$ and $\mathrm{Cd}$ are extremely low ( $<10 \%$ ) (Experiment 3$)$. The addition of $20 \mathrm{~L} \mathrm{H}_{2} \mathrm{O}_{2} / \mathrm{t} \mathrm{FA}$ increases the recoveries of $\mathrm{Pb}(60 \%)$ and $\mathrm{Cd}(86 \%)$ (Experiment 4$)$. To achieve significant recoveries for $\mathrm{Cu}, 40 \mathrm{~L} \mathrm{H}_{2} \mathrm{O}_{2} / \mathrm{t} \mathrm{FA}$ are required (63\%) (Experiment 1). Table 4 lists the analytical results of laboratory experiment 1 as well as the mass balance calculated using Formula (3). An addition of more than $40 \mathrm{~L} \mathrm{H}_{2} \mathrm{O}_{2}$ to the ash slurry did not significantly improve $\mathrm{Cu}$ recovery (Experiment 5). In addition, the L/S-ratio did not have a large effect on the recoveries measured for the laboratory-scale experiments, at least not in the applied range between L/S 2 and 3 (Experiment 6).

Table 4. Mass balance of laboratory-scale experiment 1 .

\begin{tabular}{|c|c|c|c|c|c|}
\hline & \multirow{2}{*}{$\begin{array}{c}\text { Amount of } \\
\text { material }\end{array}$} & \multicolumn{4}{|c|}{ Elemental concentrations (ppm) } \\
\hline & & $\mathrm{Cd}$ & Zn & $\mathbf{P b}$ & $\mathrm{Cu}$ \\
\hline Fly ash (FA) & $75 \mathrm{~g}$ & $364 \pm 10$ & $47,877 \pm 2200$ & $10,080 \pm 275$ & $2942 \pm 115$ \\
\hline Scrub water & $150 \mathrm{~mL}$ & $<0.1$ & $<0.1$ & $<0.1$ & $<0.1$ \\
\hline Filter cake $^{\dagger}$ & $164 \pm 1 \mathrm{~g}$ & $48 \pm 2$ & $24,715 \pm 841$ & $2740 \pm 23$ & $1571 \pm 16$ \\
\hline Leachate & $180 \pm 3 \mathrm{~mL}^{++}$ & $128 \pm 1$ & $11,519 \pm 112$ & $3242 \pm 66$ & $879 \pm 7$ \\
\hline Mass balance & & $95 \%$ & $93 \%$ & $97 \%$ & $94 \%$ \\
\hline
\end{tabular}

${ }^{\dagger}$ dry $\left(105^{\circ} \mathrm{C}\right) .{ }^{+\dagger}$ comprising $60 \mathrm{~mL}$ of deionized water used for rinsing the filter cake.

The optimal leaching conditions determined in the laboratory for the FLUWA process at MSWI plant Linth are as follows: Extraction $\mathrm{pH}$ of 3.8, $40 \mathrm{~L} \mathrm{H}_{2} \mathrm{O}_{2} / \mathrm{t} \mathrm{FA}$ and a L/S of 2 (Experiment 1). These parameters served as a basis for the optimization of the industrial FLUWA process.

\subsection{Industrial-Scale Experiments}

The industrial-scale experiments at the MSWI plant Linth provided time-resolved data over one day of the FLUWA process (Figure 3). The time-resolved sampling of input-FA, leachate and filter cake allowed to determine the metal recoveries (Formulas (4) and (5)). The simultaneous $\mathrm{pH}$ monitoring in the last reactor of the FLUWA process helped to identify the potential and limitations of the recovery for the metals $\mathrm{Zn}, \mathrm{Cu}, \mathrm{Pb}$ and $\mathrm{Cd}$.

Experiment A depicted and investigated the "current state" of the FLUWA process before any optimizations. $\mathrm{No}_{2} \mathrm{O}_{2}$ was added during this experiment and the $\mathrm{pH}$ value and L/S ratio were not adjusted regularly. The concentration of $\mathrm{Cu}$ (2648 to $2927 \mathrm{mg} / \mathrm{kg}$ ) and $\mathrm{Cd}(250$ to $320 \mathrm{mg} / \mathrm{kg})$ in the input-FA were rather constant within the entire day (Figure 3). On the other hand, the concentration of $\mathrm{Zn}(46,830$ to $80,300 \mathrm{mg} / \mathrm{kg})$ and $\mathrm{Pb}$ ( 8743 to $10,680 \mathrm{mg} / \mathrm{kg}$ ) that enters the FLUWA process with the input-FA was increasing at the beginning of the process and decreasing again with increasing process duration. Depending on the different composition of the FA added to the FLUWA process, the $\mathrm{pH}$ value and metal recovery show strong fluctuations over time (Figure 3). The $\mathrm{pH}$ value of the ash slurry in reactor 3 started low ( $\mathrm{pH} 2)$ and gradually increased over time, leveling off at ca. pH 6 at the end of the process. Under these conditions, little $\mathrm{Cu}$ and $\mathrm{Pb}$ could be recovered throughout the day. Less $\mathrm{pH}$ and redox sensitive elements such as $\mathrm{Zn}$ and $\mathrm{Cu}$ could be recovered better under the prevailing conditions. Especially Zn showed a constant recovery between 58 and $68 \%$, whereas the recovery of $\mathrm{Cd}$ fluctuated in the range of 34 to $69 \%$. 


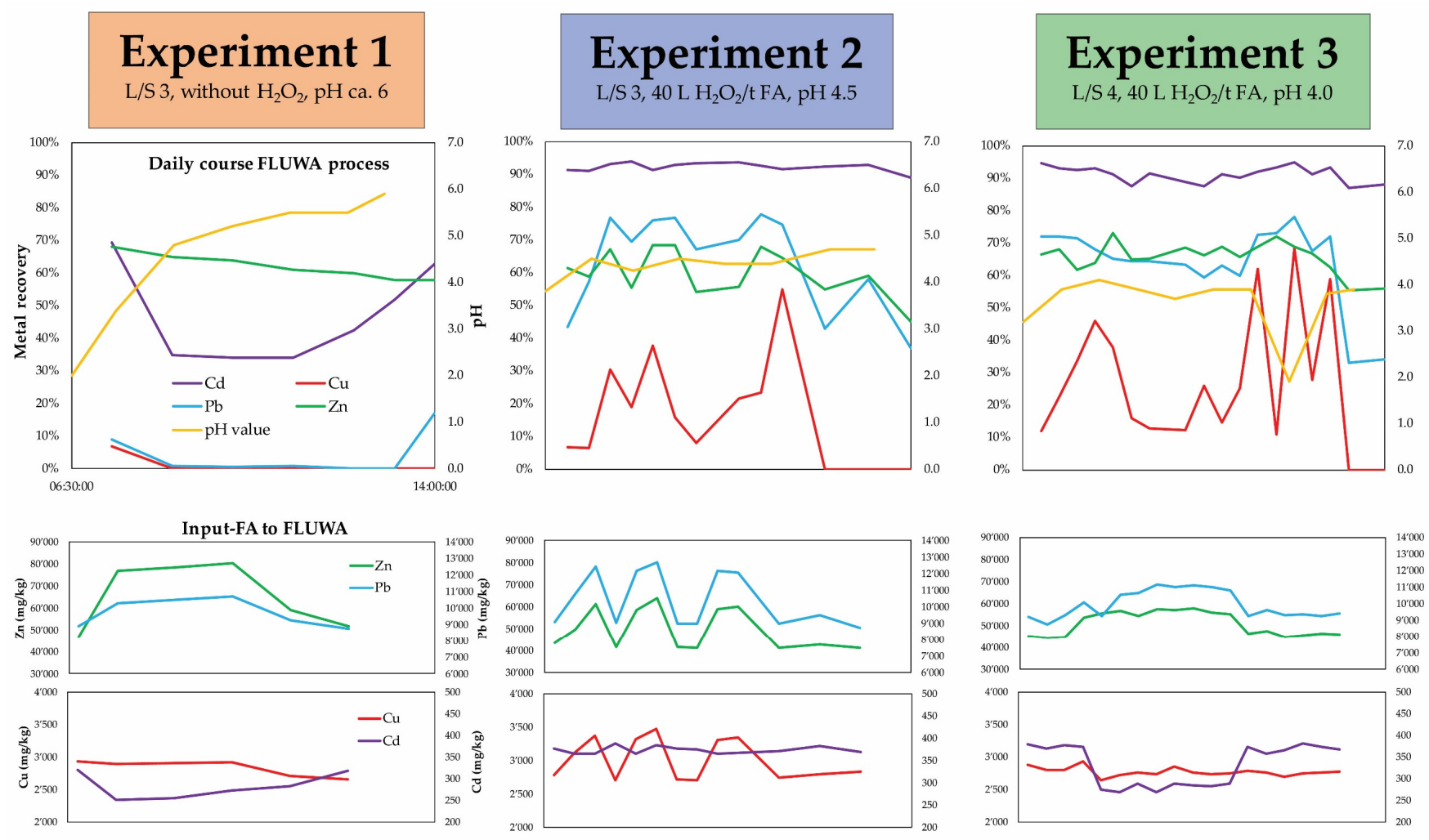

Figure 3. Results of the daily course of the three industrial-scale experiments of the FLUWA process at MSWI plant Linth. The concentrations in the input-FA (mg/ $\mathrm{kg}$ ) and the recoveries (\%) of the metals $\mathrm{Zn}, \mathrm{Pb}, \mathrm{Cu}$ and $\mathrm{Cd}$ as well as the $\mathrm{pH}$ value at the end of the process are shown for each experimental day.

In Experiment B, the initial plan was to be able to better control the $\mathrm{pH}$ by a lower FA dosing (increased L/S) and to introduce oxidizing leaching conditions. However, the input-FA dosage could be reduced only slightly due to the large quantities of FA present and the limited capacities in the storage silos. Thus, the L/S-ratio was on a daily average at the same value as in Experiment A (L/S 3). In addition, large concentration fluctuations of $\mathrm{Zn}(41,080$ to $63,860 \mathrm{mg} / \mathrm{kg}), \mathrm{Pb}$ (9498 to $12,670 \mathrm{mg} / \mathrm{kg}$ ) and $\mathrm{Cu}(2699$ to $3474 \mathrm{mg} / \mathrm{kg}$ ) in the input-FA affected the extraction recovery during this experiment. Despite these difficult conditions, it was possible to keep the $\mathrm{pH}$ value at a lower level than in Experiment $\mathrm{A}$ by the additional dosage of $\mathrm{HCl} 32 \%$. The $\mathrm{pH}$-value at the end of the leaching process in reactor 3 was maintained at $\mathrm{pH}$ 4.5. In addition to the more acidic leaching conditions, oxidizing conditions were established with the addition of $40 \mathrm{~L} / \mathrm{t} \mathrm{H}_{2} \mathrm{O}_{2}$ to the FLUWA process. The recoveries of $\mathrm{Pb}, \mathrm{Cu}$ and $\mathrm{Cd}$ were significantly better due to the oxidizing, more acidic leaching conditions compared to Experiment $\mathrm{A}$. The daily curves of the leaching recoveries of $\mathrm{Zn}, \mathrm{Pb}$ and $\mathrm{Cu}$ show a clear correlation with the concentrations of the added inputFA. The higher the concentrations of FA, the higher the metal recovery. For $\mathrm{Cd}$, no such correlation is apparent, and the recoveries are very stable at a high level.

Experiment $C$ was again performed under oxidizing conditions using $40 \mathrm{~L} / \mathrm{t} \mathrm{H}_{2} \mathrm{O}_{2}$. However, the input-FA was homogenized compared to experiment $\mathrm{B}$ by mixing the FA of the different storage silos before dosing ( $\mathrm{Zn}(44,520$ to $57,990 \mathrm{mg} / \mathrm{kg}$ ), $\mathrm{Pb}$ (9222 to $11,100 \mathrm{mg} / \mathrm{kg}), \mathrm{Cu}$ (2645 to $2929 \mathrm{mg} / \mathrm{kg}), \mathrm{Cd}$ (269 to $381 \mathrm{mg} / \mathrm{kg})$ ). In addition, the FA dosage could be reduced leading to a leaching L/S-ratio of 4 . The higher L/S led to the $\mathrm{pH}$ value being kept more stable at $\mathrm{pH} 4.0$ during the entire experimental day. Due to the more homogenic FA-input and the more stable process $\mathrm{pH}$-value, the recoveries for $\mathrm{Zn}$ and $\mathrm{Pb}$ were much more stable during the day. Despite the stable input concentrations, however, there were still exceptionally large fluctuations in the $\mathrm{Cu}$ recovery during Experiment $\mathrm{C}$. 
In addition to the daily course shown in the mean recoveries for $\mathrm{Zn}, \mathrm{Pb}, \mathrm{Cu}$ and $\mathrm{Cd}$ over the entire day of the industrial-scale experiments are listed in Table 5. It can be summarized that the recovery of $\mathrm{Zn}$ remains at a very stable level (60-70\%), irrespective of the adjustments made, whereas for $\mathrm{Cd}$, the recovery could be increased from $52 \%$ to $>90 \%$. For the more $\mathrm{pH}$ - and redox-sensitive elements $\mathrm{Pb}$ and $\mathrm{Cu}$, increased recoveries were also achieved with the optimization experiments, but at a lower level ( $\mathrm{Pb} 11 \%$ to $66 \%, \mathrm{Cu} 0 \%$ to $30 \%)$.

Table 5. Mean recoveries of $\mathrm{Zn}, \mathrm{Pb}, \mathrm{Cu}$ and $\mathrm{Cd}$ of the industrial-scale experiments of the FLUWA process within one day at MSWI plant Linth.

\begin{tabular}{ccccc}
\hline Experiment & Zn [\%] & Pb [\%] & Cu [\%] & Cd [\%] \\
\hline $\mathrm{A}$ & 66 & 11 & 0 & 52 \\
$\mathrm{~B}$ & 60 & 65 & 21 & 92 \\
$\mathrm{C}$ & 67 & 66 & 30 & 91 \\
\hline
\end{tabular}

The results of the industrial-scale experiments have shown that it is difficult to implement the ideal leaching conditions determined in the laboratory on a large-scale. For this reason, experiments were carried out in the laboratory with the materials (FA and scrub water) and conditions ( $\mathrm{pH}$, Eh and L/S) obtained at the large scale-experiments. This allows a direct comparison of laboratory- and industrial-scale experiments (Figure 4). The results show that the recoveries for $\mathrm{Cd}, \mathrm{Pb}$ and $\mathrm{Zn}$ in the laboratory were comparable to those of the industrial-scale experiments. However, despite the detailed reconstruction of the operating conditions, large deviations could be observed in the recovery of $\mathrm{Cu}$. Laboratory-scale experiments show higher leaching recoveries for $\mathrm{Cu}(7 \%, 50 \%$ and $68 \%)$ compared to the corresponding industrial-scale experiments $(0 \%, 22 \%$ and $30 \%)$.

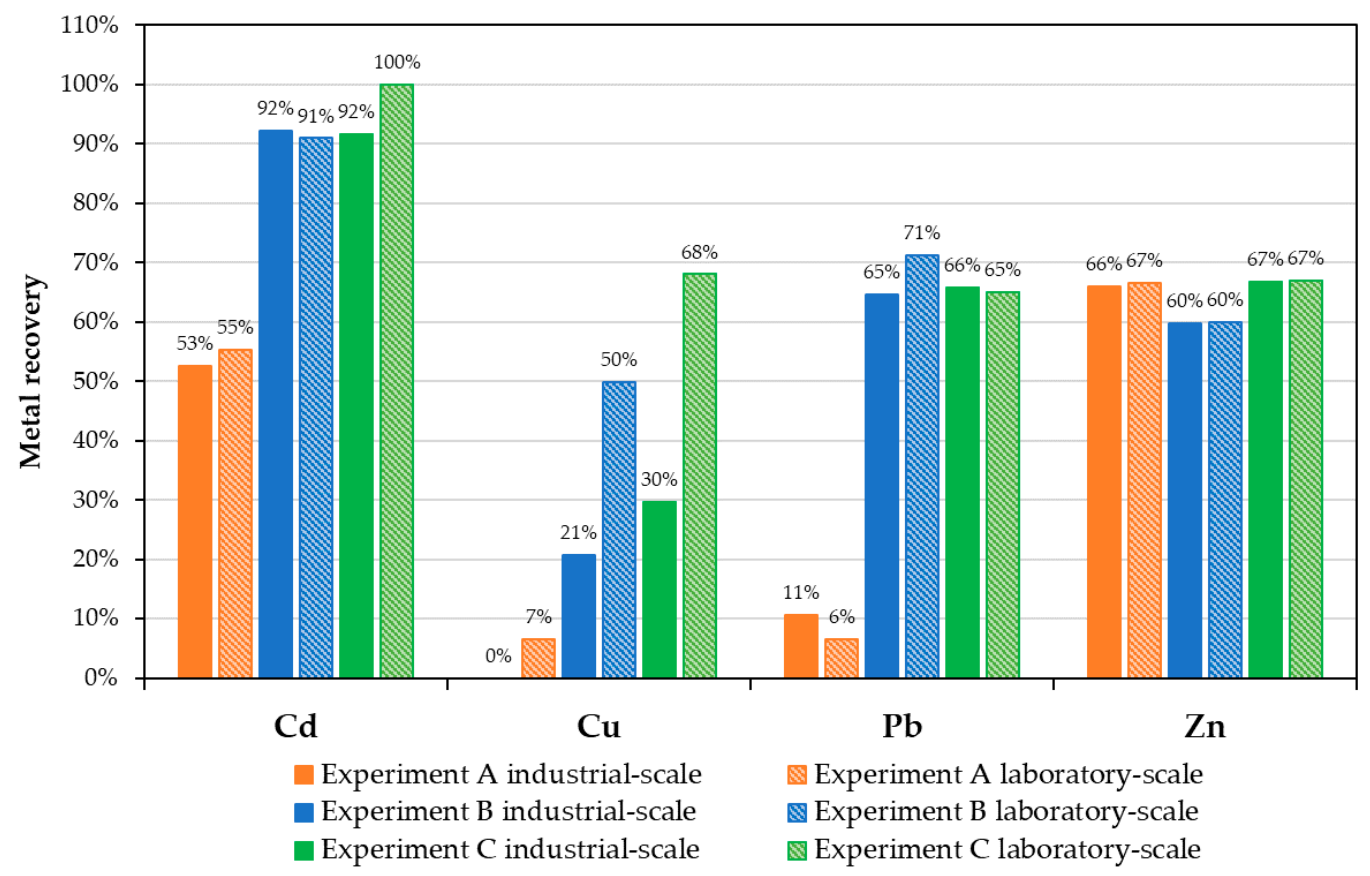

Figure 4. Metal recoveries of the FLUWA process of the three industrial-scale experiments and the corresponding laboratoryscale experiments.

\section{Discussion}

\subsection{Process Stability and Leaching Behaviour of $\mathrm{Zn}, \mathrm{Cu}, \mathrm{Pb}, \mathrm{Cd}$}

The recovery of $\mathrm{Zn}$ for both laboratory and industrial-scale experiments were between $60 \%$ and $70 \%$ regardless of the conditions (Figure 4). The use of $\mathrm{H}_{2} \mathrm{O}_{2}$ had no influence 
at all, whereas an increased L/S-ratio and lower $\mathrm{pH}$ value slightly but not significantly increased the recovery (Figure 2). Zn recovery thus seems to mainly depend on its input concentration and binding forms. The more $\mathrm{Zn}$ is present in FA, the more can usually be mobilized [15].

The redox conditions during extraction are of central importance for the recovery of redox-sensitive elements such as $\mathrm{Cu}\left(\mathrm{E}^{\circ}:+0.35 \mathrm{~V}\right), \mathrm{Pb}\left(\mathrm{E}^{\circ}:-0.31 \mathrm{~V}\right)$ and $\mathrm{Cd}\left(\mathrm{E}^{\circ}:-0.40 \mathrm{~V}\right)$. Without the addition of $\mathrm{H}_{2} \mathrm{O}_{2}$, the reducing conditions during the FLUWA process led to the cementation reaction of dissolved $\mathrm{Cu}^{2+}, \mathrm{Pb}^{2+}$ and $\mathrm{Cd}^{2+}$ on the surface of less noble metals present in the FA, such as $\mathrm{Al}^{0}\left(\mathrm{E}^{\circ}:-1.66 \mathrm{~V}\right), \mathrm{Zn}^{0}\left(\mathrm{E}^{\circ}:-0.76 \mathrm{~V}\right)$ or $\mathrm{Fe}^{0}\left(\mathrm{E}^{\circ}:-0.41 \mathrm{~V}\right)$ (Reaction Equation (6)).

$$
3 \mathrm{Cu}^{2+}+2 \mathrm{Al}^{0} \rightarrow 3 \mathrm{Cu}^{0} \downarrow+2 \mathrm{Al}^{3+}
$$

The addition of $\mathrm{H}_{2} \mathrm{O}_{2}$ to the FLUWA process oxidizes most of the metallic components in FA, resulting in more noble metals such as $\mathrm{Cu}$ and $\mathrm{Pb}$ being retained in solution and thus recovered (Reaction Equation (7)).

$$
2 \mathrm{Al}^{0}+3 \mathrm{H}_{2} \mathrm{O}_{2}+6 \mathrm{H}^{+} \rightarrow 2 \mathrm{Al}^{3+}+6 \mathrm{H}_{2} \mathrm{O}
$$

The recoveries for $\mathrm{Cu}$ and $\mathrm{Pb}$ are further strongly dependent on the $\mathrm{pH}$ value during the leaching process. The time-resolved monitoring of the process conditions in reactor 3 have shown that in a continuous process, the L/S-ratio significantly influences process stability (Figure 3). This is by enhancing or diminishing the effects of naturally occurring fluctuations in both FA and acid scrub water compositions [2]. The FA as well as the scrub water composition depend strongly on the waste input as well as the type and condition of the flue gas cleaning system or dust removal system. They show large variations over time, even in one MSWI plant. In addition to varying heavy metal concentrations, FA also differ in terms of their alkalinity. The carbonate present in the FA thereby buffers the $\mathrm{pH}$ of the suspension to $>5$, which promotes hydroxide precipitation of the metals dissolved from the FA [21]. In order to keep the extracted metals in solution, the $\mathrm{pH}$ in the leaching reactors usually has to be lowered with additional $\mathrm{HCl}(32 \%)$. The amount of acid required to reach a certain $\mathrm{pH}$ during the FLUWA process varies depending on the FA extracted. The lower the $\mathrm{L} / \mathrm{S}$-ratio, the more difficult it is to maintain a constant $\mathrm{pH}$ value. With a $\mathrm{pH}$ value of $\leq 3.8$ at the end of the FLUWA process, the hydroxide precipitation of most metals can be kept at a satisfactorily low level. The hydroxide precipitation can be well demonstrated by laboratory-scale experiments (Figure 2). An increase in $\mathrm{pH}$ value of 0.7 units between a value of 3.8 and 4.5 led to lower recoveries of $\mathrm{Pb}$ and $\mathrm{Cu}$. $\mathrm{Cu}$ begins to precipitate as copper hydroxide (or basic copper salts) at a $\mathrm{pH}$ of 4.0-4.5 and thus accumulates in the leached filter cake (Reaction Equation (8)) [22].

$$
\mathrm{Cu}^{2+}+2 \mathrm{OH}^{-} \rightarrow \mathrm{Cu}(\mathrm{OH})_{2} \downarrow
$$

In addition to hydroxide precipitation, $\mathrm{Pb}$ can also form poorly soluble sulfates and hence be removed from the leachate by lead-sulfate precipitation [22]. The sulfate supplied by the scrub water does mainly precipitate as gypsum. If the sulfate load in the scrub water exceeds the $\mathrm{Ca}$ available from the $\mathrm{FA}, \mathrm{Pb}$ can form lead sulfate and hence precipitates. This problem can be somewhat alleviated as lead has the ability to form chloride complexes, which in turn are relatively soluble [23]. Alternatively, the scrub water could be treated with a Ca containing reagent in order to reduce the sulfate load before the leaching. As the $\mathrm{pH}$ value strongly affects whether the extracted metals re-precipitate and are thus lost, it is important that the $\mathrm{pH}$ value of the leachate is closely monitored.

\subsection{Comparability Between Laboratory-and Industrial-Scale Experiments}

An important aspect of the present project was to verify the transferability of the FLUWA process parameters determined by laboratory-scale experiments to operational practice. Generally, there is a good agreement between the laboratory-scale and the corresponding industrial-scale experiments (Figure 4). Therefore, laboratory-scale experiments 
are appropriate to simulate the large-scale FLUWA process. Operating parameters determined in the laboratory for optimal recoveries of heavy metals could further be implemented on a large-scale. In the laboratory, the variation of the L/S-ratio had only a small influence on heavy metal recoveries because there, the complication of temporal change of FA composition present at the industrial scale is omitted. $\mathrm{Cu}$, reacting most sensitive to slight $\mathrm{pH}$ value and redox condition changes, is however more challenging to reliably extract on the industrial-scale in comparison to the laboratory-scale leaching. This can be explained by the fact that the $\mathrm{pH}$ value in the laboratory reactor can be controlled more precisely than during continuous, large-scale operation.

\section{Conclusions}

This work has confirmed the importance of a stable process control of the FLUWA in order to achieve a high metal recovery. This is particularly important for the recovery of $\mathrm{pH}$ and redox-sensitive elements such as $\mathrm{Cu}$ and $\mathrm{Pb}$. Important parameters for a high metal recovery are the use of a suitable oxidizing agent (e.g., hydrogen peroxide) and precise $\mathrm{pH}$ control to assure maintenance of a final $\mathrm{pH} \leq 3.8$ to avoid metal precipitation. Stable process control can be achieved through good mixing of FA as well as elevated L/S-ratio. The optimal leaching parameters have to be determined and adjusted periodically. FLUWA process parameters for one MSWI plant cannot directly be applied to another plant and must be evaluated in laboratory-scale experiments for each specific FLUWA process. With this study it could be successfully demonstrated that this transferability of laboratory-scale experiments into the operational practice is possible.

Author Contributions: Conceptualization, G.W., A.Z. and U.E.; methodology, G.W., A.Z., U.E. and S.S.; formal analysis, G.W., A.Z.; investigation, G.W., A.Z.; resources, G.W.; data curation, G.W., A.Z.; writing—original draft preparation, G.W., A.Z.; writing-review and editing, M.W., S.R., U.E.; visualization, G.W., A.Z.; supervision, U.E., S.S.; project administration, G.W.; funding acquisition, G.W., U.E. All authors have read and agreed to the published version of the manuscript.

Funding: This research was partially funded by MSWI plant Linth, where the industrial-scale experiments were also performed. Further funding was provided by the Swiss Federal Office for the Environment (FOEN) and the association of operators of swiss waste treatment industrials (VBSA).

Acknowledgments: Many thanks to Markus Stäger, Walther Gasser and Thomas Heckendorn (KVA Linth) for their technical support during sampling and industrial-scale experiments. Special thanks to Urs Eggenberger (U.E., University of Bern), Stefan Schlumberger (S.S., ZAR) for project feedback and discussion. Analytical support and assistance with experiments by Andreas Glauser and Christine Lemp (University of Bern) is highly acknowledged.

Conflicts of Interest: The authors declare no conflict of interest.

\section{References}

1. Federal Office for the Environment (FOEN). Indikator Abfall. 2016. Available online: https://www.bafu.admin.ch (accessed on 30 October 2020).

2. Zucha, W.; Weibel, G.; Wolffers, M.; Eggenberger, U. Inventory of MSWI Fly Ash in Switzerland: Heavy Metal Recovery Potential and Their Properties for Acid Leaching. Processes 2020, 8, 1668. [CrossRef]

3. Bayuseno, A.P.; Schmahl, W.W. Characterization of MSWI fly ash through mineralogy and water extraction. Resour. Conserv. Recycl. 2011, 55, 524-534. [CrossRef]

4. Katsuura, H.; Inoue, T.; Hiraoka, M.; Sakai, S. Full-scale plant study on fly ash treatment by the acid extraction process. Waste Manag. 1996, 16, 491-499. [CrossRef]

5. Van der Bruggen, B.; Vogels, G.; Van Herck, P.; Vandecasteele, C. Simulation of acid washing of municipal solid waste incineration fly ashes in order to remove heavy metals. J. Hazard. Mater. 1998, 57, 127-144. [CrossRef]

6. Ludwig, B.; Khanna, P.; Prenzel, J.; Beese, F. Heavy metal release from different ashes during serial batch tests using water and acid. Waste Manag. 2005, 25, 1055-1066. [CrossRef] [PubMed]

7. Chiang, K.-Y.; Jih, J.-C.; Chien, M.-D. The acid extraction of metals from municipal solid waste incinerator products. Hydrometallurgy 2008, 93, 16-22. [CrossRef]

8. Yang, R.; Liao, W.-P.; Lin, C.-Y. Feasibility of lead and copper recovery from MSWI fly ash by combining acid leaching and electrodeposition treatment. Environ. Prog. Sustain. Energy 2012, 32, 1074-1081. [CrossRef] 
9. Tang, J.; Steenari, B.M. Solvent extraction separation of copper and zinc from MSWI fly ash leachates. Waste Manag. 2015, 44, 147-154. [CrossRef] [PubMed]

10. Quina, M.J.; Bontempi, E.; Bogush, A.; Schlumberger, S.; Weibel, G.; Braga, R.; Funari, V.; Hyks, J.; Rasmussen, E.; Lederer, J. Technologies for the management of MSW incineration ashes from gas cleaning: New perspectives on recovery of secondary raw materials and circular economy. Sci. Total Environ. 2016, 635, 526-542. [CrossRef] [PubMed]

11. Ferraro, A.; Farina, I.; Race, M.; Colangelo, F.; Cioffi, R.; Fabbricino, M. Pre-treatments of MSWI fly-ashes: A comprehensive review to determine optimal conditions for their reuse and/or environmentally sustainable disposal. Rev. Environ. Sci. Biotechnol. 2019, 18, 453-471. [CrossRef]

12. Schlumberger, S.; Schuster, M.; Ringmann, S.; Koralewska, R. Recovery of high purity zinc from filter ash produced during the thermal treatment of waste and inerting of residual materials. Waste Manag. Res. 2007, 25, 547-555. [CrossRef] [PubMed]

13. Bühler, A.; Schlumberger, S. Recovering heavy metals from fly ash "Acid fly ash leaching-FLUWA process" a forward-looking process in waste in-cineration. MSWI residues in Switzerland-The raw material with added value. Fed. Off. Environ. 2010, 1, 185-192.

14. Karlfeldt Fedje, K.; Andersson, S. Zinc recovery from Waste-to-Energy fly ash-A pilot test study. Waste Manag. 2020, 118, 90-98. [CrossRef] [PubMed]

15. Weibel, G.; Eggenberger, U.; Schlumberger, S.; Mäder, U.K. Chemical associations and mobilization of heavy metals in fly ash from municipal solid waste incineration. Waste Manag. 2017, 62, 147-159. [CrossRef] [PubMed]

16. Free, M. Hydrometallurgy Fundamentals and Applications; John Wiley \& Sons, Inc.: Hoboken, NJ, USA, 2013 ; pp. 1-427.

17. Karavasteva, M. Kinetics and deposit morphology of copper cementation onto zinc, iron and aluminium. Hydrometallurgy 2005, 76, 149-152. [CrossRef]

18. Demirkıran, N.; Ekmekyapar, A.; Künkül, A.; Baysar, A. A kinetic study of copper cementation with zinc in aqueous solutions. Int. J. Miner. Process. 2007, 82, 80-85.

19. Swiss Confederation. Verordnung über die Vermeidung und die Entsorgung von Abfällen (VVEA). Available online: https: / / www.fedlex.admin.ch/eli/cc/2015/891/de (accessed on 15 November 2020).

20. Stiftung Zentrum für Abfall- und nachhaltige Ressourcennutzung (ZAR). SwissZinc-National Plant for the Recycling of MSWI Hydroxide Sludge (Fact Sheet no. 2). 2016. Available online: https://zar-ch.ch/fileadmin/user_upload/Contentdokumente/ Oeffentliche_Dokumente/Projektblatt_SwissZinc_Nr2.pdf (accessed on 30 November 2020).

21. Hartinger, L. Handbook of Wastewater and Recycling Technology; Fachbuchverlag Leipzig: Munich, Germany, 1991; Volume 2, ISBN 978-3-446-43170-6.

22. Hollemann, A.F.; Wiberg, E. Lehrbuch der Anorganischen Chemie; Walter de Gruyter: Berlin, Deutschland, 2007; Volume 2, ISBN 978-3-11-017770-1.

23. Weibel, G.; Eggenberger, U.; Kulik, D.A.; Hummel, W.; Schlumberger, S.; Klink, W.; Fisch, M.; Mäder, U.K. Extraction of heavy metals from MSWI fly ash using hydrochloric acid and sodium chloride solution. Waste Manag. 2018, 76, 457-471. [CrossRef] [PubMed] 